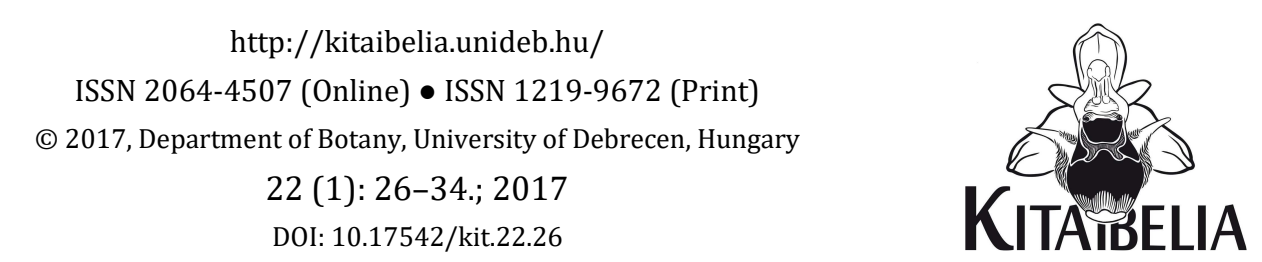

\title{
Emlékezés Felföldy Lajosra
}

\author{
SOMLYAY Lajos \\ MTM Növénytár, H-1431 Budapest, Pf. 137.; somlyay.lajos@nhmus.hu
}

A Lajos bácsi mellett töltött tíz növénytári esztendő (1993-2003), különösen az ezredforduló előtti évek, szakmai pályafutásom talán legszebb, legfelhőtlenebb szakaszát jelentette. Hozzájárult ehhez a „rendszerváltozás” időszakának reményekkel teli atmoszférája, a „most majd minden jobb lesz" szinte gyermeki (és meglehetősen naiv) lelkesedése. Az 1960-as évek óta Csipkerózsika-álmát alvó magyar flóra- és vegetációkutatás hatalmas fejlődésnek indult, köszönhetően annak a váratlan jelenségnek, amely a hazai szakintézmények elhivatott „fiataljai" (és kevésbé fiataljai), valamint az amatőr botanikusok nagymértékű és szinte egyidejű színre lépésében testesült meg. Rohamosan követték egymást a nagy jelentőségű, néha szenzációszámba menő florisztikai, vegetációtani és taxonómiai felfedezések, új flóra- és vegetációművek láttak napvilágot. Döbbenetes erővel ébredtünk rá, mennyi ismeretlent, mennyi kutatnivalót rejt hazánk növényvilága. A „fiatalok” között akkoriban még nemigen mutatkoztak a mások kárára történő egyéni érdekérvényesítés alattomos, vagy leplezetlen jelei, sokkal inkább az együttműködésen volt a hangsúly, és ezt a mozgalmat néhány „nagy öreg”, köztük Felföldy Lajos is melegen pártolta.

A korszak sajátos felszabadultsága a Természettudományi Múzeumban is határozottan érződött, a „demokratikus változások” szelét bizonyítandó, átmenetileg még kutatói tanács is működött az intézményben. A 20. század utolsó évtizedének pezsgő légkörét némelyik hivatali vezetőm hatalomcentralizáló, az „oszd meg és uralkodj” jól bevált elvét alkalmazó gyakorlata sem tudta tönkretenni. Lelki derűm megőrzésében, egyszersmind szakmai szemléletem formálásában, tudásom fejlesztésében két ember játszott főszerepet a munkahelyemen: Felföldy Lajos és Bunke Zsuzsanna.

Lajos bácsi, a magyar botanika doyenje, az első generációs Soó-tanítványok egyik utolsó élő képviselője volt. Amikor a Növénytárba kerültem (1993 augusztusa), nyugdíjasként puszta szakmaszeretetből - a Kárpát-medencei virágosnövény-gyűjtemény (Herbarium Carpato-Pannonicum) anyagát revideálta és rendezte időrendi és földrajzi alapon. A DallaTorre-rendszer szerint tárolt anyagot sorrendben, az egyszikűek elejéről (Typhaceae család) kezdte, első revíziós cédulái 1992 őszéről valók. Zavartalan munkakörülményeit a saját maga által kialakított kettős rendezőasztal és a gondosan összegyűjtött szükséges kellékek (mikroszkóp, detergens folyadék, ragasztó, viaszhengerke, bonctű stb.) biztosították. E gyűjteményt maga is rendszeresen gyarapította saját friss gyüjtéseivel. Hetvenes éveit taposva is fiatalokat megszégyenítő energiával dolgozott a terepi gyűjtőútjain és a herbáriumban egyaránt. Zsuzsa néni ellenben a saját bevallása szerint sem volt botanikus, viszont nem létezett Magyarországon hozzá fogható ember, aki a magyar flórakutatás hőskoráról, az „1830 előtt született" hazai botanikusok életéről, munkásságáról és kapcsolatrendszeréről annyit tudott volna, mint ő. Játszi könnyedséggel betűzte ki az olvashatatlannak tűnő régi herbáriumi cédulákat. Még az 1980-as évek elején különítette el önálló gyűjteményrészbe a Növénytár 
legrégebbi virágosnövény-példányait (Collectiones historicae), amit állagmegőrzési és kutathatósági szempontok egyaránt indokoltak. E részlegnek lett informális vezetője és tulajdonképpen egyetlen hazai kutatója. A növénytári kollégák többsége respektálta a tudását, de a vezetés részéről vajmi kevés elimerést kapott.

Lajos bácsi és Zsuzsa néni mindketten a herbárium, a herbáriumi munka szerelmesei voltak, és ez a „szerelem” mindenkire átragadt, aki huzamosabb időt tölthetett mellettük. Magam is nekik köszönhetem azt a megmagyarázhatatlan, kíváncsisággal és egyfajta megilletődöttséggel vegyes érzést, amely ma is hatalmába kerít egy-egy történeti értékű herbáriumi lap kézbe vételekor. „A herbáriumot szeretni kell!” - hangsúlyozta Lajos bácsi, és nála nem pusztán a gyönyörűen préselt saját példányaiból, hanem valóban minden mozdulatából sugárzott ez a szeretet. Finoman szólva igen elmarasztalóan vélekedett azokról a botanikusokról, „akiknek izzad a lába, ha a herbáriumba kell lépniük”; ez a metafora állítólag Zsuzsa nénitől származott.

A két idős kutató voltaképpen kiegészítette egymás tudását, mert Lajos bácsi - föltehetően a 19. századi herbáriumi cédulák sokszor szegényes információtartalma miatt - kevéssé értékelte a régi anyagot, míg Zsuzsa néninek az volt a mindene. Lajos bácsinál elsősorban a növény taxonómiai hovatartozása és a gyűjtés körülményeire vonatkozó adatok mennyisége és pontossága, tehát inkább az előfordulás „térképezhetősége” szabta meg egy-egy példány szakmai értékét. Igaz ugyan, hogy amikor a Herbarium Generale-ból önszorgalomból elkezdtem kiválogatni az ismeretlen okból korábban odakerült, szinte kizárólag 19. századi Kárpátmedencei lapokat, és átadtam azokat a Herbarium Carpato-Pannonicum rendezését végző Lajos bácsinak, nagy örömmel fogadta és dolgozta fel az anyagot. (Jellemző, hogy e tevékenységemet az akkori hivatali vezetőm, aki teljesen érzéketlen volt a herbárium iránt, számon kérte rajtam: „Ki bízta meg magát ezzel?”). Zsuzsa nénit szinte kizárólag a herbáriumi lapok történeti-személyi vonatkozásai érdekelték. Számára egy akár hozzávetőleges lelőhely is kapaszkodót jelentett a gyűjtő életútjának felgöngyölítésében, a példány származására vonatkozó pecsétnyomat („,ex herb. $\left.X Y^{\prime \prime}\right)$ a személyes kapcsolatrendszerre derített fényt, a préselés finomsága vagy a cédulán lévő kézírás alapján a gyűjtő emberi tulajdonságait igyekezett kipuhatolni. A két tudós ember eltérő nézőpontú okítása, magyarázatai révén jószerével mindent megtanulhattam a herbárium fontosságáról és használhatóságáról, a herbáriumi munka kulisszatitkairól. Mindenesetre nem tartoztam az „izzadó lábúak” közé, mert csaknem minden nap délután ott ültem Lajos bácsi mellett a kettős rendezőasztalnál, növényeket határoztunk, szakmai és nem szakmai beszélgetéseket folytattunk. Zsuzsa néni is mindig valahol a közelben tevékenykedett és időnként megjelent.

Szemléletbeli különbségeik néha komoly súrlódáshoz vezettek. Lajos bácsi mesélte, hogy Zsuzsa néni egy alkalommal egy történeti értékű, gyönyörűen preparált herbáriumi lapot mutatott neki lelkendezve, amelyre azonban a cédulán feltüntetett névtől eltérő növény volt ragasztva.

- És az nem zavarja, hogy a lapon nem leander, hanem orgona van? - szegezte neki a kérdést ingerülten.

- Jaj, kérem, én nem vagyok botanikus! - mentegetőzött Zsuzsa néni megszeppenve.

- Akkor miért van itt? - pattant ki a kérdés formájába csomagolt lesújtó ítélet Lajos bácsi szájából, de remélem, ezt a gorombaságot kizárólag felém tolmácsolta. Talán a színészi pályával való ifjúkori kacérkodása miatt a viselkedését mindig sajátos teatralitás jellemezte, és számtalan adomájának néha talán nem teljesen valósághủ, ám csattanós véget kreált.

A herbáriumi példányok esztétikai értékét, a gondos preparálást ugyanakkor mindketten fontosnak tartották. Ezt példázza a következő eset. Az 1980-as évek növénytári gyüjtései között - az akkori gárdát Lajos bácsi rosszallóan és részben igazságtalanul csak „Laczacsapat"-nak titulálta - igen sok a nagyon rossz állapotú vagy határozásra többé-kevésbé alkalmatlan fragmentumot tartalmazó, gyakran tévesen is határozott herbáriumi lap. 
- Mit csináljak ezzel a szeméttel? Kidobjam? - kérdezte egyszer az anyag rendezése közben Zsuzsa nénitől, mert a felfogásbeli különbségek ellenére azért időnként mégiscsak beszélgettek.

- Kérem, ezek a lapok kordokumentumok, nem szabad kidobni... - hüledezett Zsuzsa néni ijedt tekintettel.

A lapok így megmenekültek. Szégyenkezem, ha a Növénytárba látogató külföldi kutatók benyomásaira gondolok, amikor ezeket a „példányokat” kézbe veszik. Zsuzsa néninek ugyanakkor igaza volt, mert ezek a lapok valóban dokumentumok, ráadásul szakmai értelemben is, például a Duna-Tisza közi flóramű dokumentációs alapját képezik. Miután a flóramú adatait az itt dolgozó botanikusok helyett a preparátorok gyüjtötték ki annak idején a herbáriumból (!), tehát a cédulára írt nevek szakmai revízió nélkül kerültek a flóraműbe, számos téves vagy bizonytalan adat lappang benne.

Habár senkit, így magát sem tekintette tévedhetetlennek, a „tippelésen alapuló”, néha egyenesen „hajmeresztő” félrehatározások igencsak felbosszantották Lajos bácsit. Epés megjegyzések kíséretében mutatott nekem herbáriumi példányokat, amelyeken szegény Radics Feri bácsi durva tintával kesze-kuszán firkált revíziós cédulái vagy határozásai éktelenkedtek.

- Most nézd meg! - tolta elém Andrasovszky József egyik meghatározatlanul hagyott lapját. Radics rávéste a cédulára, hogy Carex praecox $\times$ nitida ... és milyen rondán!!!, pedig a példány egyszerűen csak Carex supina. Még a vélt szülők közé sem tudta betippelni a helyes fajnevet! Lacza-csapat ... - morogta csak úgy magának a fejét csóválva, majd hirtelen felém fordult:

- Hogy lehet úgy valaki botanikus, hogy nem csak nem ismeri a fajokat, de azt sem tudja, hogyan kell növényt határozni?

Egy másik alkalommal elborzadva mesélte, hogy a minap itt járt „valami diák” („XY, ismered?"), aki a saját gyűjtését a növénytári herbáriumi anyaggal való felületes összehasonlítás alapján próbálta meghatározni. A szóban forgó növény történetesen egy apró minőségi bélyegek alapján azonosítható füféleség volt, amelyhez binokuláris mikroszkóp is szükségeltetett.

- Törte, zúzta a herbáriumot, úgyhogy kénytelen voltam leállítani és megtanítani neki, hogyan kell a határozókönyvet használni - vázolta Lajos bácsi a történteket.

Amikor az ominózus példány faji azonosságára a „közösen lefolytatott” határozás végén fény derült, az illető „Hát így is lehet?” felismerését Lajos bácsi nyers „Csak így lehet!” kijelentéssel torkollta le, s közben úgy megnyomta a „CS” betűt, hogy az illető bizonyára egy életre megtanulta a leckét. Még a történet puszta felidézése is idegessé tette Lajos bácsit, s váltig bizonygatta, hogy efféle dilettantizmus Soó professzor egykori diákjainál nem fordulhatott volna elő. Bevallottam, hogy ismerem az illetőt, és valójában nem diák, hanem egyetemi oktató. Percekig nem szólalt meg, de elképedt arckifejezésére ma is emlékszem.

Sajátosan pragmatikus szemlélete a Növénytárban rendelkezésre álló tárolótér általa optimálisnak vélt kihasználásában is megmutatkozott. A duplumként értékelt lapokat - legalábbis egy időszakban - igyekezett elkülöníteni, sőt egyszer arra is (sikertelen) kísérletet tett, hogy a duplumanyag a Növénytár egy másik részlegében akkor még üresen álló szekrényekbe kerüljön elhelyezésre. A duplumok kijelölésében azonban más szempontot, mint az „adott taxon, adott gyűjtőtől, adott helyen és időpontban” információ-együttes, nem nagyon ismert. Például az a körülmény, hogy típusanyagról van-e szó, egyáltalán nem érdekelte.

A kapcsolatom Lajos bácsival távolról sem csak a herbáriumi munkára szorítkozott. Ha egy szakmai kérdés kapcsán tanulságos történet jutott eszébe, vagy egyszerűen belefáradt a határozásba, nem nagyon kellett unszolni, hogy a régi dolgokról, saját életéről, az általa anynyira imádott Balatonról meséljen. Nagy szerencse, hogy ezek jelentős részét írásban is közreadta (FELFÖLDY 2000). Egyetlen fontosabb részletre emlékszem, ami a Soó Rezsőről szóló 
írásból kimaradt, de nekem szóban többször is említette, ez pedig Soó szakmai féltékenységből fakadó „viszonyulása” Jávorka iránt. Lajos bácsi visszaemlékezéséből értelemszerűen kimaradtak életének azon szakaszai is, amelyeket nem Soó Rezső mellett töltött. Ezek közül említek néhány, az elmondása alapján gondosan feljegyzett adatot vagy emlékeimben őrzött momentumot.

Még a debreceni évei alatt, 1942 és 1943 nyarán belföldi kutatóösztöndíjjal a tihanyi biológiai intézetben ismerkedett meg a kísérletes laboratóriumi munkával, Győrffy Barna irányítása alatt. Itt sajátította el azokat a módszereket, amelyekkel a II. világháború után megkezdhette a hazánkban úttörőnek számító citogeográfiai kutatásait, immár Tihanyban. Miután azonban az „elvtársak” tagadták a kromoszómák létezését, a témát az Akadémia 1949-ben hatalmi szóval letiltotta (Lajos bácsi ezzel kapcsolatban Faludi Béla nevét emlegette). Az akadémia biológiai osztálya utasítására ezután úgymond "növényi vegetatív hibrideket” kellett (volna) létrehozni, amelyeknél az oltvány termésén, illetve generatív utódjain az alany előnyös hatása kimutatható. A tudományosan képtelen elvárást nem lehetett visszautasítani, ezért Lajos bácsi és munkaközössége paradicsomoltványokkal kezdett kísérletezni. Közben (1952) áthelyezték a vácrátóti kutatóintézetbe, ahonnan rövidebb katonai szolgálatra hívták be. A kísérleti paradicsomtövek gondozását ezért az intézet kertészére bízta. Amikor az év végén visszatért, a kertész büszkén jelentette, hogy a növényeket megkülönböztetett figyelemmel gondozta, és a termésük igen csak ízletesnek bizonyult...

Meglepőnek tűnhet, hogy ilyen „kudarc” után az akkori „tudományos minősítő bizottság” - az idézőjel Lajos bácsi értékítéletét hivatott kifejezni - mégis a biológiai tudományok kandidátusává nyilvánította, ráadásul védés nélkül (1953. július 22.). Lajos bácsi mesélte, hogy akkoriban a bizonyos pozíciókban levő személyek (intézetvezetők, osztályvezetők, egyetemi tanárok) automatikusan megkapták ezt a címet, míg a tudományos kutatókat legföljebb felterjeszthették erre. Őt magát a tihanyi intézet igazgatója, Horváth János terjesztette fel, és az odaítélésről szóló vitán a világszerte elismert hidrobiológus, Maucha Rezső akadémikus állt ki mellette.

1954-ben visszakerült Tihanyba. Az idő tájt néhány évig növényi szárazságtűréssel is foglalkozott, majd 1955-től „,kísérletes algológiai” feladattal bízták meg. Mint mesélte, ez alapjában véve baktériummentes algatörzsek előállítását célozta, de a téma fedőneve alatt jóval tágabb horizontú tudományos kérdéseket feszegető méréseket és kísérleteket is folytatott munkatársaival. A nádas sáv vízminőség-módosító szerepe, a vízi anyagforgalom általános törvényszerűségei, ahogy ő maga fogalmazta: a „természet törvényeinek megismerése” már akkor is intenzíven foglalkoztatták. Tihanyi munkásságának ez az „experimentális” időszaka (mennyire megvetette ezt a szót!) kerek tíz esztendeig tartott, de a jelentős eredmények ellenére kutatásait az intézet pár évvel korábban kinevezett igazgatója - Lajos bácsi szavait idézve - „a munkakörülményeket ellehetetlenítve” 1965-ben gyakorlatilag leállította. A tihanyi évekről mégis jó kedvvel mesélt. Az általa semmire nem tartott személyeket, a „ködevőket”, a „köldöknézőket”, azokat a szakmailag tehetségtelen embereket, akik mások segítségével futottak be fényes karriert, fanyar humorral parodizálta. A „cím- és rangkórság”gal szembeni mély ellenérzésére jellemző példa, hogy amikor pár évtizeddel később egy-két bennfentes az akadémiai doktori cím felé igyekezett terelni, elhárította az invitálást.

1965-ben áthelyezték a Vízgazdálkodási Tudományos Kutató Központ Vízminőségvédelmi Intézetébe, ahol főmunkatársi, majd tudományos tanácsadói minőségben működött. A VITUKI-ban - anyagi okokból - elsősorban külső megbízásos, gyakorlati feladatokon kellett dolgoznia, amelyeknek olykor nem hogy botanikai, de még vízügyi vonzata sem nagyon volt. Egy ilyen témát föl is jegyeztem: algagranulátum előállítása állati takarmányozás céljából... Hatvanévesen, 1980-ban ment nyugdíjba, és valójában ezután teljesedett ki vízbiológiai munkássága, amelynek kezdetei, mint láttuk, a tihanyi évekre nyúlnak vissza. E helyen csak egyetlen eredményét emelem ki, amely azonban mindennél jobban rávilágít Lajos bácsi ké- 
pességeire. A nádas sáv eutrofizálódást fékező, tápanyag-eltávolító szerepének, illetve e mechanizmus biológia-kémiai hátterének megértése vezette arra a megsejtésre, hogy más kémiai elemekhez (szén, nitrogén, kén) hasonlóan a foszfor is képes a redukáló baktériumok közreműködése révén, gáz formájában távozni a vízi ekoszisztémából (így, „e”-vel, mert ezt tartotta a helyes írásmódnak).

- De La-jos-kám..., azt már régen kimutatták volna!!! - tamáskodott az egyik szakmai kollégája, de nem zárkózott el attól, hogy az ötletet precíz kísérlet tárgyává tegye.

Lajos bácsi föltevése igazolódott, az erről szóló négyszerzős publikáció a világ vezető természettudományos folyóiratában, a Nature-ben jelent meg 1988-ban.

Nemcsak az életútjáról mesélt szívesen, hanem kedvteléseiről is. Imádta a költészetet, a pajzánt (Lőwy Árpád) és klasszikust egyaránt. Gyakran idézte Ady vagy Vörösmarty sorait.

- Most mondd meg, hogy volt képes ez a géniusz leírni?: „Az emberfaj sárkányfog vetemény...”; „Sárkányfog”, „sárkányfog” - ízlelgette a kifejezést és a csodálata jeléül kissé megrázta a fejét: „Elképesztő!”

Máskor Ady istenes verseiből idézett, vagy - a saját munkásságára utalva - átszellemülten szavalta:

„Susogó nádak mezejében járok,

Királyi bottal csapkodok kevélyen,

És zúg a nádas csúfondáros mélyen,

Királyi bottal valamerre járok.

Értem a titkot, a nádi beszédet,

Susog a nádas s én messzekiáltok:

Nádi világ, im, megjött királyod,

Midrásznak sarja szállott, im, elébed."

Nagyon szeretett énekelni. Ha olyan hangulata volt, munka közben egy fél délutánon át régi nótákat dúdolt. Vagy fölemelte fejét a herbáriumi vizsgálódásból, hátradőlt a székén, arcát a két tenyerébe fogta, emlékei távolába nézett, és elhomályosult szemmel lassan elkezdte:

„Elveszett a lovam citrusfaerdőbe’

Csizmám is elszakadt babám

A nagy keresésbe'.

Ne keresd a lovad, mer' bé van az fogva,

Debreceni kertek alján,

Szól a csengő rajta." nok.

- Jaj, de szép! - suttogta aztán maga elé. Gyönyörű volt. Mint azok a felejthetetlen délutá- 
Lajos bácsi nagy volumenű növénytári revíziójának és az ebből is fakadó kiváló fajismeretének gyorsan híre ment az országban, amelynek eredményeként számos budapesti és vidéki „fiatal” fordult hozzá szakmai segítségért, illetve mutatta be neki saját gyűjtött anyagát ellenőrzés céljából. Precíz, pontos határozása vagy a gyűjtő provizórikus határozásának megerősítése után bárki nyugodt lélekkel közölhette adatát az akkoriban gombamódra szaporodó hazai botanikai folyóiratok valamelyikében (többnyire a Kitaibelia-ban). Kezdőként az ember, ha számára ismeretlen faj akad az útjába, hajlamos apró fragmentumokat tépkedni, úgymond „az is megteszi határozás céljából”. Aztán akár megteszi, akár nem, mindenképpen kidobja. A herbáriumi munka „kultúrája” Magyarországon - ha beszélhetünk egyáltalán ilyesmiről - a rendszerváltozás előtti évtizedekben olyan mélyre süllyedt, hogy mai fejjel úgy gondolom, ha nincs Felföldy Lajos bácsi, identifikáció céljából talán ma is növénydarabkákat tépdesnénk vagy a digitális fényképezőgépet nyomogatnánk. Egyértelműen neki köszönhető, hogy legalább néhányan az országban komolyan elkezdtünk növényt gyüjteni. Nem emlékszem olyan esetre, hogy bárki fragmentális anyaggal merészkedett volna Lajos bácsi elé, de ha volt ilyen, az illető biztos nem tette zsebre, amit kapott. Viszont egy szépen préselt példány láttán Lajos bácsi arca rögtön felragyogott, és nem fukarkodott az elismerő szavakkal.

Nehezebb esetekben a herbáriumi revízióhoz vagy az új példányok azonosításához jó határozókönyv szükségeltetik. Lajos bácsi a legjobbnak Jávorka alapmunkáit, a „nagyjávorkát” (Flora Hungarica), illetve annak a trianoni Magyarországra adaptált kistestvérét, a „kisjávorkát” (A magyar flóra kis határozója), továbbá a Soó Rezsővel közösen jegyzett (de túlnyomórészt Jávorka kulcsait tartalmazó) kétkötetes művet ( $A$ magyar növényvilág kézikönyve) tekintette, és főként ezeket használta munkája során. Revíziós céduláin viszont többnyire Soó szinopszisának nómenklatúráját követte. Mindamellett igyekezett felhasználni az újabb külföldi szakmunkák, monográfiák eredményeit is. Az infraspecifikus taxonok (alfajok, változatok, formák) meghatározására nagy hangsúlyt fektetett, azokat számos esetben fizikailag is elkülönítette a herbárium rendezése során. A bonyolultabb vagy nagy fajszámú nemzetségek esetén saját használatra részletes határozókulcsot szerkesztett. Ezek a kulcsok az irodalmi források találó megállapításait és saját herbáriumi tapasztalatait „összegyúrva” készültek, tehát autopszián alapultak. Igazán jó kulcsot de novo írni nehéz feladat. A szükséges botanikai ismereteken túl komoly áttekintő és logikai képességeket igényel, mert egy kulcs annál jobb, minél könnyebben és gyorsabban ér el annak használója az ismeretlen növény megfejtéséig, a tézisek-antitézisek láncolata pedig minél kevesebb buktatót tartalmaz. Lajos bácsiban megvolt ez a képesség; írógéppel készült határozókulcsai - szemben némelyek bevett gyakorlatával - sohasem német vagy angol kulcsok kvázi fordításai voltak, nem is beszélve a hazai infraspecifikus taxonok gondos beillesztéséről. Többször emlegette nekem, hogy kellene írni egy jó terepi határozókönyvet, a „kisjávorka” mai tudásunknak megfelelő javított és kiegészített változatát.

„Kulcskészítő" tehetségének az egyik legszebb példája a hazai sásfajok feldolgozása. Miután a Herbarium Carpato-Pannonicum rendezését az egyszikű családokkal kezdte, éppen a 90-es évek közepén került sor a sokszor komoly határozási nehézséget jelentő sások revíziójára. 1996-ban a tanulni vágyó „fiatalok” - Lajos bácsi szakmai vezetésével, mintegy fővédnökségével - „Sásismereti kurzus”-t rendeztek Sopronban. Itt gyorsan fölmerült egy olyan munka terve, amely a hazai sások határozókulcsát, részletes morfológiai leírását, fontosabb jellemzőjét (elterjedés, cönológiai karakter stb.) és ábraanyagát egyaránt tartalmazza. Lajos bácsi kézirata, amely az összes leíró részt tartalmazta, 1997 novemberére elkészült. Utóbb bevallotta nekem, hogy szerette volna az ábraanyagot is maga rajzolni, de a kurzuson az a megegyezés született, hogy az ábrákat az egyik fiatal barátunk fogja összeválogatni különböző flóraművekből. A munka végül komoly csúszással látott napvilágot 2002-ben, és Lajos bácsit ez meglehetősen elkedvetlenítette. 
Ezzel szinte párhuzamosan egy másik, még nagyobb horderejű kezdeményezés is történt. Még az első, Debrecenben tartott „Aktuális flóra- és vegetációkutatások Magyarországon” című konferencián (1997) - amely a bevezetőben említett „pezsgő” korszak emblematikus eseményének tekinthető - merült föl egy új terepi növényhatározó megvalósításának gondolata. A finanszírozással kapcsolatban fölmerült sajátos nehézségek, és talán az akkori évek lázas „terepbotanikai” munkálkodása, a párhuzamosan futó - mi magunk által is türelmetlenül sürgetett - egyéb, szintén nagy horderejű kezdeményezések (könyv a hazai védett fajokról, flóratérképezési program) is késleltették az előrelépést ebben a kérdésben. Végül 2000 februárjában az Aggteleki Nemzeti Park akkori igazgatójának, Salamon Gábornak a védnöksége alatt kétnapos megbeszélésre gyültünk össze Jósvafőn. A találkozó célja az új növényhatározó gyakorlati megvalósításának megtervezése és az ehhez szorosan kapcsolódó személyi feladatkörök rögzítése volt. Az eseményen az idősebb korosztályból csak a hazai rózsák szakértője, Facsar Géza tanár úr és természetesen a „rangidős” Lajos bácsi vettek részt. Máig emlékszem Lajos bácsi jelentőségteljes mozdulatára, amint az asztal mellett ülő társaságnak fölmutatta Jávorka kis határozóját:

- Ezt kell a mai tudományos ismereteknek megfelelően kiegészíteni és javítani!

A különböző vélemények megvitatása után végül megállapodás született egy kétkötetes (szöveges és ábrás) mű fő tartalmi paramétereiről. Miután mi, akkori "fiatalok" szakmai szempontból egyenrangúnak számítottunk, magától értetődően egyikünk sem vindikált magának „előjogokat”, a találkozón föl sem merült, hogy a határozó szerkesztője ne Lajos bácsi legyen, akit a "fiatalok” többségének osztatlan tisztelete övezett. Erről akkor határozott döntés született. Ugyancsak kijelölésre kerültek a „családfelelősök”, egyáltalán, rögzítettük a munka megvalósításának gyakorlati lépéseit, az egyes résztvevők feladatait. Az ANP igazgatója vállalta a könyv elkészítésének teljes anyagi finanszírozását. Mindenki nagy lelkesedéssel látott munkához.

Aztán hamarosan valami megváltozott. A 2000-es évek elején a munka valahogy sehogyan sem akart haladni. Lajos bácsi, aki a szerkesztői föladatok mellett a szöveges részek többségének elkészítését is vállalta, többször panaszkodott nekem ezzel kapcsolatban. Ő ugyan „határidőre” szálí́tja az anyagot, de mi van a többiekkel, már lektorálnia, szerkesztenie kellene az elkészült részeket, egyáltalán, miért hiányzik a szükséges kommunikáció Aggtelek részéről. Értetlenül álltunk a dolog előtt, de ő maga, 80 évesen, természetesen nem tett különösebb lépést a helyzet tisztázására. Egyre többször emlegette viszont, hogy kilép az egész vállalkozásból. Szándékáról mindig igyekeztem lebeszélni. Tény, hogy az eredeti megállapodástól eltérően, Lajos bácsi központi szerepe e nagyszabású vállalkozásban - a háttérben lezajlott, számunkra eleinte még ismeretlen történések, illetve személyi változások következtében - lassan (?) elhalványult. Később (2004) az ANP gondozásában készülő határozóról szóló beszámolóban már csak lektorként jelent meg a neve. Végül 2009-ben, amikor az új határozó megjelent, nem járult hozzá, hogy az általa írt kulcsok a neve alatt szerepeljenek...

A történetben azonban még az új évezred legelején járunk. A tennivaló rengeteg, intenzíven folyik a hazai botanikai kutatómunka, a jelentősebbnél jelentősebb florisztikai felfedezések és adatközlések folyama mintha nem akarna apadni, új arcok, új motivációk tűnnek fel, de a 90-es évek közepén a "fiatalok” körében tapasztalt „egy hajóban evezés” összetartó és lelkesítő érzése mintha kezdene szertefoszlani.

Lajos bácsi töretlen energiával folytatta a növénytári herbárium rendezését, időnként azonban hosszabb-rövidebb időre otthon maradt, hogy a növényhatározó egy-egy fejezetén dolgozzon. A régi meghitt beszélgetésekre így egyre ritkábban jutott idő. Aztán a rendezés „rendje” is megbomlott, mert az egyik új növénytári kolléga megkérte Lajos bácsit, engedje meg, hogy a soron következő néhány növénycsalád revízióját maga végezhesse el. Habár ez nem igazán tetszett Lajos bácsinak, a mákféléket, kereszteseket, rezedaféléket, varjúhájfélé- 
ket és ribiszkeféléket átugorva, 2002 őszén a rózsafélék családjának egyes kritikusabb nemzetségeihez fogott. Emlékszem, még én kölcsönöztem neki szakirodalmat (Terpó Pyrusmonográfiáját és Kárpáti Sorbus-monográfiáját). Ez az anyagrész további bosszúságot okozott számára, mert az említett monográfiák színvonalát összességében elégtelennek találta, ezért a nagy számú növénytári példány azonosítása és rendezése tekintetében jószerével csak e feldolgozások megállapításaira hagyatkozott.

Beköszöntött a 2003. esztendő. Pusztán a történések hátterének megértéséhez írom le, hogy az idő tájt a növénytári virágos kutatók közül nekem voltak a legkiterjedtebb külföldi, főleg orosz kapcsolataim, mert az orosz botanikusok - az akkor még fennálló kétoldali akadémiai egyezmény alapján - nagy számban látogatták a gyújteményünket. Így esett, hogy 2003 őszén két szentpétervári botanikust, a sásfélék családjának (Cyperaceae) világhírü kutatóját, Tatiana Egorova professzor asszonyt és fiatal tanítványát, Ivan Tatanov-ot láttam két hétre vendégül a Növénytárban. Egorova a Carex nemzetség bizonyos szekcióit, Tatanov pedig az egész Bolboschoenus nemzetséget kívánta tanulmányozni a Herbarium CarpatoPannonicum-ban. Hol biztosítsak számukra megfelelő munkalehetőséget, lehetőleg közel egymáshoz? Teljesen nyilvánvaló volt, hogy az egyetlen alkalmas hely Lajos bácsi kettős rendezőasztala, nemcsak a megfelelő mérete és stabilitása, hanem legfőképpen a fizikai elhelyezkedése miatt, ugyanis az egyszikűek termében, éppen a sásfélék közvetlen közelében állt (és áll ma is). Miután Lajos bácsi elég sok időt töltött otthoni munkával, föl sem merült bennem, hogy ez a megoldás ellenére lenne. Telefonon hívtam fel - akkor is éppen otthon dolgozott - és udvariasan megkértem, hadd ültessem majd a hamarosan érkező két orosz vendéget a kettős asztalhoz. Ecseteltem neki a körülményeket, az elhelyezés ésszerűségét; meg aztán az idős professzor asszonyt nem ültethetem egy labilis alumíniumasztalhoz, és ha Lajos bácsi közben a Növénytárba jönne, ideiglenesen egy másik asztalnál folytathatja a rendezést. Nem állítom, hogy kitörő örömmel fogadta a kérésemet, de némi tanakodás után látszólag beleegyezett, és abban maradtunk, hogy majd hívom, ha a vendégek elmentek. Álmomban nem gondoltam volna, milyen következményei lesznek ennek az epizódnak. Amikor elérkezett az idő, örömmel hívtam Lajos bácsit, de a telefonból akkor már kiéreztem, hogy nagyon nagy a baj. Lajos bácsi vérig volt sértve. Bejött a Növénytárba, óriási patáliát csapott, s habár Boncz Emi néni próbálta csitítani, összepakolt és hazament. Leszámolt a Növénytárral (utólag derült ki, hogy a rendezést ezután a Füvészkert jóval kisebb és áttekinthetőbb herbáriumában folytatta). Nem akartam hinni a fülemnek, teljesen megdermedtem a döbbenettől. Hogy viselkedhetett így velem? (Jellemző, hogy az ember ilyenkor mindig a saját sérelmét érzékeli.) Velem, akivel tíz évig olyan szoros szakmai és emberi kapcsolatban volt... Rettenetesen igazságtalannak éreztem Lajos bácsi viselkedését. Olyasféle érzések kavarogtak bennem, mint amiket ő maga írt le szemléletesen a Soó Rezsővel történt kolozsvári összeveszésük kapcsán. A történelem ismétli önmagát?

Időre volt szükségem, hogy rendet rakjak a gondolataim között és ráeszméljek a régi igazságra: „Ad poenitendum properat qui cito iudicat.” Igazságtalanság történt? Dehogy. Egyszerűen nagy szamárságot csináltam. Nem vettem figyelembe egy szellemileg ugyan friss, de mégiscsak 83 éves idős ember érzékenységét. Azt sem vettem figyelembe, hogy akkoriban számos kisebb-nagyobb bosszúság érte a sáshatározó és a növényhatározó miatt, valamint a rendezés körüli anomáliával kapcsolatban. Azt hiszem, elege lett a „fiatalokból”. (Más lehetséges magyarázatra nem is merek gondolni.) Az eset azonban valamire rávilágított. Nehéz leírnom, de ma már úgy gondolom, hogy Lajos bácsihoz, legalábbis a "fiatalok” közül, senki nem állt igazán közel, talán az óriási korkülönbség miatt sem állhatott. Minden segítséget megadott nekünk, mesélt, tanáccsal szolgált, a jó kezdeményezések lelkes pártfogója volt, gondosan lektorálta a közölni szánt anyagainkat, gyakran közösen mentünk terepre, de mindvégig magának való ember maradt, akinél „a természet törvényeinek” vizsgálata, az elmélyült kutatómunka önmagában is abszolút boldogságot, teljes értékủ életet biztosított. 
Mai eszemmel természetesen másképpen - bár most sem tudom, hogyan - szervezném akkori vendégeim látogatását, de hát késő bánat, ebgondolat.

Évek múlva találkoztam vele ismét. A Növénytárba készült valamilyen ügyben, de a kor már kikezdte erejét. A Könyves Kálmán körúton, az akkori pénzverde kerítésének padkáján pihent, erőt gyűjtve a Növénytárig hátralevő száz méter megtételéhez. Beszélgettünk, és nyoma sem volt már benne sértődöttségnek. Mikor említettem, hogy Erdélyországba készülök botanizálni, szelíden elmosolyodott, szemei megteltek könnyel, tekintete a távolba révedt. Talán a régi kincses város kopottas utcái vagy a Meszes hegység zöldellő lankái elevenedtek meg a lelki szemei előtt, ki tudja... E szelíd mosollyal az arcán maradt meg az emlékezetemben.

Beérkezett: 2017. 02. 21. • Elfogadva: 2017. 03. 01. 